\title{
Obtaining and evaluation of enzymatic extract from Aspergillus spp. by saccharification of sour cassava starch liqued
}

\section{Obtención y evaluación de un extracto enzimático de Aspergillus spp. para la sacarificación de almidón de yuca licuado}

\section{Recolha e avaliação de um extracto de enzima de Aspergillus spp. para a sacarificação da mandioca amido liquefeito}

\author{
Andrés M. Rueda1; Luis J. Rueda²; Daniel Molina V.1,2; Clara I. Sánchez ${ }^{3 *}$

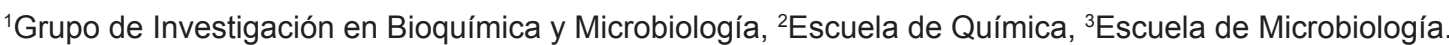 \\ Universidad Industrial de Santander, Bucaramanga, Santander, Colombia. \\ *cisanche@uis.edu.co
}

Fecha Recepción: 20 de diciembre de 2016

Fecha Aceptación: 11 de agosto de 2017

\begin{abstract}
The saccharification enzymes are more expensive than liquefaction enzymes for that reason are sought strategies that allow the supply of these enzymes at low cost. The objectives of this study were to evolve saccharolytic enzymatic extracts from native strains, to select an extract and to determine the best variables for the production of glucose syrups from liquefied bitter cassava starch. Thirteen mushrooms isolated from sour cassava (Manihot $\mathrm{sp}$ ). were evaluated for their saccharolytic activity, hydrolysis of maltose, glucose production and biomass formation in submerged fermentation. Aspergillus A1 was selected because it had the highest volumetric activity $\left(0.09 \mathrm{UI} . \mathrm{L}^{-1}\right)$. During solid-state fermentation, the presence of proteins was corroborated by electrophoresis SDS-PAGE. Through various experiments, the best experimental condition were $\mathrm{pH} 4.0$, agitation Or.p.m and temperature $55.0^{\circ} \mathrm{C}$; the effect of cofactors $\mathrm{Cu}^{2+}, \mathrm{K}^{+}, \mathrm{Mg}^{2+}$ and $\mathrm{Na}^{+}$was evaluated, $\mathrm{Mg}^{2+}$ increases the activity in $1.32 \mathrm{Ulmg}^{-1}(32.4 \%)$. The thermal stability at $55.0^{\circ} \mathrm{C}$ is 120 minutes. Finally, the saccharolytic capacity of the enzymatic extract was confirmed using liquefied cassava starch.
\end{abstract}

Keywords: Glucoamylase, Aspergillus, Saccharification, Syrup Glucose.

\begin{abstract}
Resumen
Comercialmente las enzimas de sacarificación son más costosas que las de licuefacción, por tal razón se buscan estrategias que permitan el suministro de estas enzimas a bajo costo. Los objetivos de este estudio fueron evaluar extractos enzimáticos sacarolíticos a partir de cepas nativas, seleccionar un extracto y determinar las mejores variables para la producción de jarabes de glucosa. Para ello, en trece hongos filamentosos aislados de yuca amarga Manihot sp. fueron evaluadas la actividad sacarolítica, la hidrólisis de maltosa, la producción de glucosa y la formación de biomasa bajo condiciones de fermentación sumergida. El aislamiento identificado como Aspergillus A1 fue seleccionado por presentar la más alta actividad volumétrica $\left(0,09 \mathrm{UI} . \mathrm{L}^{-1}\right)$. Durante la fermentación en estado sólido se corroboró la presencia de proteínas mediante el método de electroforesis SDS-PAGE y se evidenció una banda de mayor intensidad con peso molecular entre 60 y $70 \mathrm{kDa}$. Para el extracto enzimático de Aspergillus A1 se determinó que las mejores condiciones experimentales de sacarificación, con el uso de maltosa como sustrato, fueron $\mathrm{pH} 4,0$, temperatura $55,0^{\circ} \mathrm{C}$, y sin agitación. Igualmente en la evaluación del efecto de los cofactores $\mathrm{Cu}^{2+}, \mathrm{K}^{+}, \mathrm{Mg}^{2+}$ y Na${ }^{+}$en concentraciones de $1 \mathrm{mM}$, se observó que todos incrementan la
\end{abstract}


actividad enzimática especialmente el $\mathrm{Mg}^{2+}$, el cual la aumenta en 1,32 Ul. $\mathrm{mg}^{-1}$ (32,4\%). La estabilidad térmica de la proteína a $55,0^{\circ} \mathrm{C}$ fue de 120 minutos. La capacidad sacarolítica del extracto enzimático fue confirmada usando como sustrato almidón de yuca amarga licuado.

Palabras clave: Glucoamilasa, Aspergillus, Sacarifcación, jarabes de glucosa.

\section{Resumo}

Comercialmente as enzimas de sacarificação são mais custosas do que as de liquefação, por esta razão procuram-se estratégias que permitam fornecer este tipo de enzimas a baixo custo. Os objetivos deste estúdio foram avaliar extratos enzimáticos sacarolīticos de cepas nativas, selecionar um extrato e determinar as melhores variáveis para a produção de xaropes de glicose. Para isto, de treze fungos filamentosos isolados de mandioca amarga Manihot sp., foram avaliadas a atividade sacarolítica, a hidrólise de maltose, a produção de glicose e a formação de biomassa em condições de fermentação submersa. O isolamento Aspergillus A1 foi selecionado por apresentar a maior atividade volumétrica $\left(0,091 \mathrm{UI} . \mathrm{L}^{-1}\right)$. Durante a fermentação em superfície a presença de proteínas foi confirmada pelo método de eletroforese de SDS-PAGE junto com uma banda de maior intensidade com peso molecular entre os 60 e 70kDa. Para os preparados enzimáticos de Aspergillus A1 determinou-se que as melhores condições experimentais de sacarificação usando maltose como substrato foram $\mathrm{pH} 4,0$, temperatura de $55,0^{\circ} \mathrm{C}$, sem agitação. Igualmente na avaliação do efeito dos cofatores $\mathrm{Cu}^{2+}, \mathrm{K}^{+}, \mathrm{Mg}^{2+}$ e $\mathrm{Na}+$ em concentrações de $1 \mathrm{mM}$, observou-se que todos incrementam a atividade enzimática principalmente o $\mathrm{Mg}^{2+}$ em 1,32Ul. $\mathrm{mg}^{-1}(32,4 \%)$ em relação ao controle. A estabilidade térmica da proteína de $55,0^{\circ} \mathrm{C}$ é de 120 minutos. A capacidade sacarolítica do extrato enzimático foi confirmada usando substrato hidrolisado de mandioca amarga.

Palavras-chave: Glucoamilase, Aspergillus, Sacarificação, xarope de glicosa.

\section{Introduction}

World cassava production has increased in the last years, reaching 270.2 million of tons by 2014 [1]. Starch from sour cassava is a cheap source to produce ethanol. Starch pretreatment process, involve the breaking of amylose and amylopectin by enzymes, being these the costliest step in the ethanol production from starch, around $47 \%$ of total value, mainly by the enzymes price [2].

One example is the use of saccharolytic enzymes for the hydrolysis of starch in obtaining fermentable syrups for bio-ethanol production, which reduces time and generates fewer residues compared with traditional acid hydrolysis [3]. Enzymatic extracts are commercially available for liquefaction and saccharification of corn and sorghum starch, highcost raw materials that compromise food security. However, for cassava starch, which is not suitable for human consumption, no commercial enzymes for hydrolysis exist in the market. In addition, sour cassavas abound greatly in Latin America.

Glucose syrups can be obtained via chemical or enzymatic hydrolysis of starch [4]. In chemical hydrolysis, the use of acids increases the cost of production, unwanted products are formed, and wastes can pollute the environment. In contrast, enzymatic hydrolysis is a cheaper alternative that produces less pollution. However, due to the complexity of the structure of starch, it is necessary to incorporate heat treatment and the use of different enzymes to ensure the highest conversion of this polymer to glucose [5].

The enzymatic hydrolysis of starch is carried out in two steps: liquefaction and saccharification. In the first step, a-amylase (EC 3.2.1.1) is used to make cuts at random into the internal structure of starch due to endo-enzyme activity, generating many products such as pullulan, dextrin and glucose. The pullulan and dextrin are not viable to be used in the alcoholic fermentation process because they are not absorbed by fermenting microorganisms. Saccharification can occur by two enzymes: pullulanase (EC 3.2.1.41), which only breaks $\alpha-1.6$ bonds and produces mostly dextrins, disaccharides such as maltose and a very small amount of glucose; and glucoamylase (EC 3.2.1.3 and EC 3.2.1.20), which hydrolyzes a $-1,4$ glycosidic terminal bonds of dextrins from starch liquefaction, forming mainly glucose. The pullulanases are produced mostly by bacteria, and glucoamylases are produced by fungi [6].

Enzymatic saccharification is expensive and thermally unstable. The enzymatic process is 
performed at high temperatures because this improves solubility, decreases viscosity of the starch, reduces microbial contamination, decreases the process time and reduces production costs [7]. The bio-fuel industry seeks to replace the enzymes used in the industrial processes of starch hydrolysis with enzymes having higher thermostability [8]. These enzymes can be obtained from wild type microorganisms because in some cases, native enzymes exhibit better catalytic activity than commercial enzymes [9].

For production of enzymes with saccharolytic activity from filamentous fungi, the genera Aspergillus and Rizhopus have been the most studied using solid state fermentation (SSF) [10]. Native fungal enzymes also have been shown to viably be used for glucose obtaining on an industrial scale.

The aim of this project was the isolation, identification and selection of native filamentous fungi with saccharolytic activity, and to obtain an enzymatic extract from the optimal isolation to be used in glucose syrup production from maltose and cassava starch.

\section{Materials and methods}

For primary isolation of fungi, sour cassava (Manihot $s p$ ) was collected with evident fungal colonization from two farms in rural Barrancabermeja, Santander, Colombia. Ten grams of sour cassava was chopped, homogenized and diluted in $90 \mathrm{ml}$ of sterile saline solution. Each suspension from cassava homogenized dilutions were taken to obtain fungal colonies by surface culture. Sub-cultures were made to obtain axenic strains from the isolations at $25^{\circ} \mathrm{C}$ [11]. The culture media used contained maltose $\left(5 \mathrm{~g} . \mathrm{L}^{-1}\right)$ as the only carbon source, rose bengal to restrict microbial growth and chloramphenicol $\left(0.1 \mathrm{~g} \cdot \mathrm{L}^{-1}\right)$ as a broad-spectrum antibiotic.

Genus of Isolated fungi were identified by macroand microscopic characteristics using taxonomic keys. The culture media for identification was potato dextrose agar (PDA).

Submerged fermentation (SF) was performed in flasks of $250 \mathrm{~mL}$ in sterile conditions, each flask contained $50 \mathrm{~mL}$ of basal media in deionized water with the following per L: maltose (5), $\mathrm{KH}_{2} \mathrm{PO}_{4}$ (5), $\mathrm{MgSO}_{4} \cdot 7 \mathrm{H}_{2} \mathrm{O}$ (5), peptone (2) and yeast extract (1). $\mathrm{SF}$ was made to determine maltose consumption and production of glucose, protein and biomass. Each flask was adjusted to a final concentration of $10^{5}$ propagules $\mathrm{mL}^{-1}$. Each batch of SSF isolations had twenty-five flasks, the fermentation was held with agitation at $150 \mathrm{rpm}$ and incubate at $25^{\circ} \mathrm{C}$ for 72 hours. Every eight hours, one flask and two replicates were taken to obtain the enzymatic extracts, the biomass was separated from the broth using filtration through a Büchner funnel with Whatman No. 1 filter paper, and the enzymatic extract was obtained by vacuum.

A first screening of the enzymatic extract was performed by evaluating maltose hydrolysis and glucose production using 3,5-dinitrosalicylic acid (DNS) [12] and glucose oxidase (Biosystems $®$ ) [13], respectively. Volumetric productivity was calculated based on glucose production. The maltose concentration was calculated via subtraction of the concentration of reducing sugars and glucose. The production of glucose, protein by Bradford method [14], and biomass by dry weight and the hydrolysis of maltose were determined in a second screening. The isolation with the best results was named Aspergillus A1. The enzymatic volumetric activity (UI.L-1) of the enzymatic extract from this isolation was quantified (Figure 1). The enzymatic volumetric activity (UI.L-1) was defined as micromoles of glucose produced per $\mathrm{ml}$ in one minute at $50^{\circ} \mathrm{C}$ and $200 \mathrm{rpm}$.

To increase the protein concentration from the enzymatic extract, SSF of Aspergillus A1 was performed in a column bioreactor with a lignocellulosic support sterilized at $121^{\circ} \mathrm{C}$ for $15 \mathrm{~min}$. The column bioreactor was filled with $8 \mathrm{~cm}$ of support and $150 \mathrm{ml}$ of broth. The crude enzymatic extract was obtained by pressing the lignocellulosic polymer, followed by centrifugation at $10000 \times \mathrm{g}$ for 15 minutes and finally filtering (Millipore, cellulose $0.45 \mu \mathrm{m}$ ).

Electrophoresis SDS-PAGE was performed on enzymatic extracts obtained by SSF of Aspergillus A1 to determine the molecular weight of the proteins present in the extract. A Fermentas PageRuler of 10 to $200 \mathrm{kDa}$ was used as a molecular weight standard. Samples were run at 120 volts in $12 \%$ polyacrylamide gels using Coomassie blue as the dye.

Analysis of variance was performed to establish the highest values of enzymatic activity of the enzymatic extract from Aspergillus $\mathrm{A} 1$ at a $\mathrm{pH}$ $3-9$, a temperature of $30-90^{\circ} \mathrm{C}$ and an agitation of $0-600 \mathrm{rpm}$. The results of this analysis were used to determine the best experimental conditions for maltose hydrolysis. The independent variables were $\mathrm{pH} 4.0 ; 4.5$ and $5.0 ; 16 \mathrm{mmol}^{-\mathrm{L}^{-1}}$ buffer sodium acetate and $0,1 \mathrm{molL}^{-1}$ citric acid; temperatures of 55,60 and $65^{\circ} \mathrm{C}$; and agitation at 0,200 and $400 \mathrm{rpm}$. The experiments were performed in tubes 
containing $1 \mathrm{~mL}$ of enzymatic extract and $1 \mathrm{~mL}$ of maltose at a concentration of $5 \mathrm{mgmL}^{-1}$. The response variable was the glucose concentration versus time. Each assay was performed in triplicate, and the results were analyzed using Statgraphics software.

The effect of $1 \mathrm{mmolL}^{-1}$ aliquots of cofactors $\mathrm{Cu}^{2+}$, $\mathrm{K}^{+}, \mathrm{Mg}^{2+}$ and $\mathrm{Na}^{+}$on enzymatic extract activity was determined per the methodology of Bhatti et al. [15]. This was performed based on the optimized conditions found in the experimental design. The thermal stability of the enzymatic extract was also evaluated at $55^{\circ} \mathrm{C}$ through glucose quantification every 15 minutes for 3 hours.

Finally, the saccharolytic activity of the selected enzymatic extract was evaluated using the optimized parameters for the best cofactor on fermentable syrups obtained from liquefied cassava starch. Liquefied cassava starch was obtained according to the methodology described by Ruiz et al. [16].

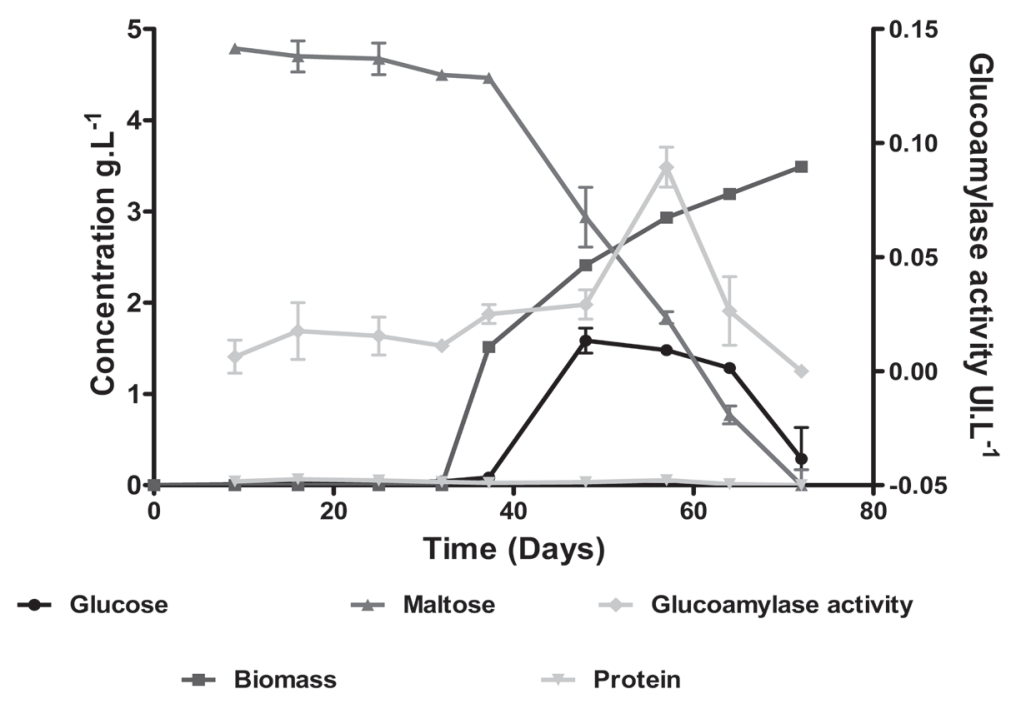

Figure 1. Growth curve of Aspergillus A1 submerged fermentation.

\section{Results and Discussion}

From samples of sour cassava, it was possible to obtain 13 fungal isolations belonging to the genera Fusarium, Penicillum, Geotrichum, Scopularipsis and Aspergillus, and all the isolations showed saccharolytic activity. The two isolations with the best volumetric productivity were Aspergillus A1 and Aspergillus A12 with 0.07 and $0.05 \mathrm{gL}^{-1}$, respectively. The isolation that showed the best production of glucose from maltose was Aspergillus A1 (1.3 $\left.\mathrm{gL}^{-1}\right)$ between 50 and 60 hours of fermentation. This agrees with the highest volumetric enzymatic activity from extract obtained at the same time, despite a low protein concentration, as shown in Figure 1.

Based on the volumetric activity, glucose production from maltose hydrolysis was confirmed in all fungal isolations, with the fungi of genera Aspergillus having the best productivity. The previous results confirm that the Aspergillus genus had the highest glucose syrup production by submerged fermentation [17,18]. Authors such as Riaz et al [19]. and O'Brien et al [20], have suggested several species of Aspergillus, including A. awamori, $A$. foetidus, $A$. niger, $A$. oryzae, $A$. terreus, for glucose syrups obtaining from polysaccharides.

The enzymatic extracts obtained from submerged fermentation of Aspergillus A1 did not reach a higher concentration of protein $\left(0.05 \mathrm{~g} \cdot \mathrm{L}^{-1}\right)$. This contrasted with SSF, where it was possible to obtain concentrations greater than $0.05 \mathrm{~g} \cdot \mathrm{L}^{-1}$.

The increase in protein concentration in the enzymatic extract was possible with the change from submerged fermentation to solid fermentation with a lignocellulose support. With this variation, the protein concentration reached $0.06 \mathrm{~g} . \mathrm{L}^{-1}$. This is consistent with the work of Rodríguez et al [21], and Singhania et al [22], who concluded that use of SSF for obtaining enzymatic extracts is better than the concentrations achieved by submerged fermentation. The electrophoresis SDS-PAGE results of enzymatic extracts obtained from SSF of Aspergillus A1 showed 11 bands with different molecular weights. The band with a molecular weight between 60 and 70kDa had the highest intensity, as shown in Figure 2. 


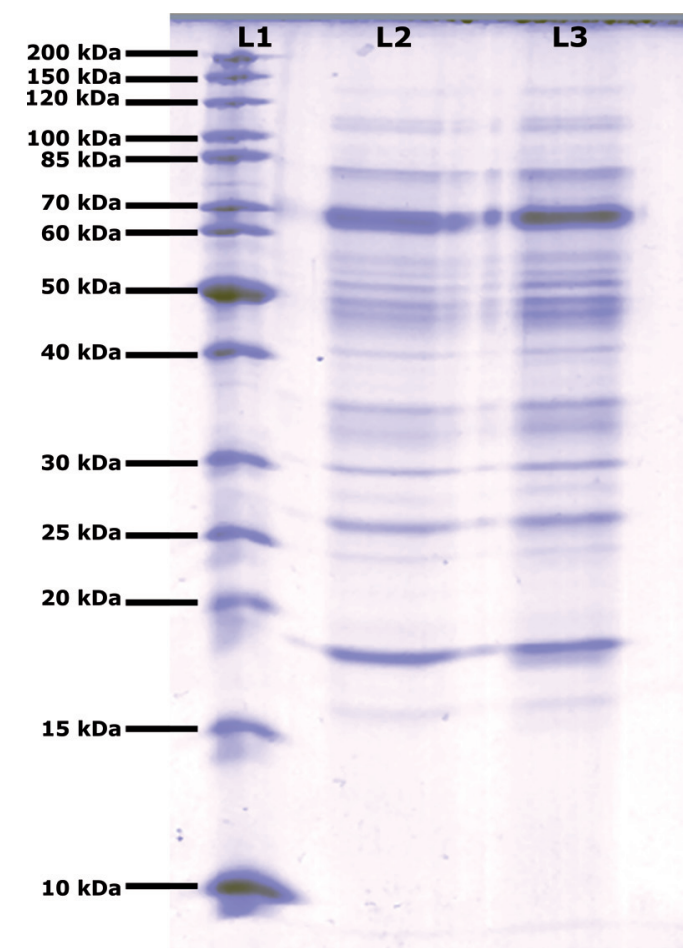

Figure 2. Polyacrylamide gel electrophoresis of enzymatic extract from Aspergillus A1 obtained by SSF. Line 1 Molecular weight marker; Lines 2 and 3 enzymatic extract from Aspergillus $\mathrm{A} 1$ from two different bioreactors. Coomassie brilliant blue G-250 staining.
The bands observed in gels from SDS-PAGE obtained from different SSF of enzymatic extracts from Aspergillus A1 were not different from each other, guaranteeing the reproducibility of SSF, as shown in Figure 2. The band with the highest intensity occurred between 60 and $70 \mathrm{kDa}$. These results corroborate those of Norouzian et al., ${ }^{8}$ who established the molecular weights of fungal glucoamylases to be within a range of 48 to $90 \mathrm{kDa}$. da Silva et al [23] and Bagheri et al [24] reported the molecular weight of glucoamylase from Aspergillus niveus to be $76 \mathrm{kDa}$.

Analysis of variance showed that the best saccharolytic activity of the extract at $\mathrm{pH}$ values between 4 and 5, agitation between 200 and $600 \mathrm{rpm}$ and a temperature of $60^{\circ} \mathrm{C}$. By using these values, it was possible to define the variables for the experimental design matrix.

As can be seen in Figure 3, the best enzymatic extract activity from Aspergillus A1 with respect to $\mathrm{pH}$ occurs at 20 minutes, $\left(4.4 \mathrm{Ul} . \mathrm{mg}^{-1}\right)$ at a $\mathrm{pH}$ between 4 and 5 and at $60^{\circ} \mathrm{C}$. Under these conditions, the activity reached $3.5 \mu \mathrm{mol} . \mathrm{L}^{-1}$. These results are comparable to those of Bagheri et al [24], who reported that the highest activity of glucoamylase occurs at a pH between 4.5 and 6.5 and at temperatures between 50 and $70^{\circ} \mathrm{C}$.
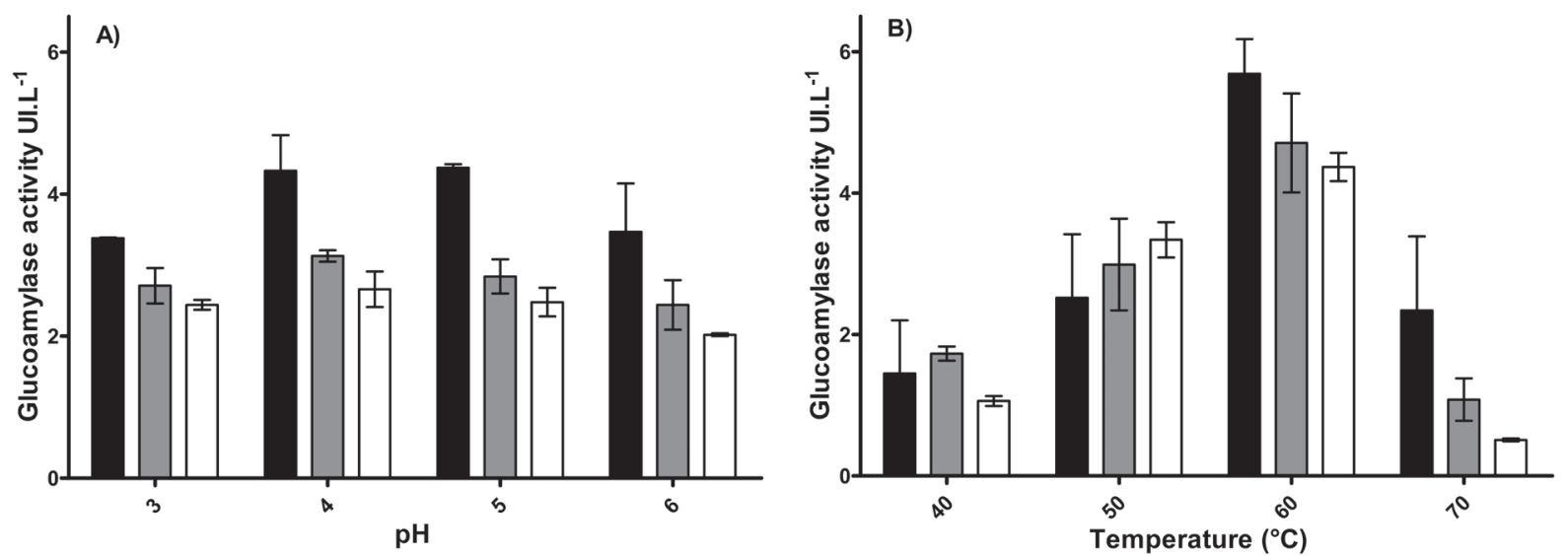

Figure 3. Glucoamylase activity under the effect of different values of $\mathrm{pH} 3-6(\mathrm{~A})$ and temperature $40-70^{\circ} \mathrm{C}(\mathrm{B})$, using maltose to concentration $5 \mathrm{mg} \cdot \mathrm{mL}^{-1}$ like a substrate. (black bars) glucoamylase activity at $20 \mathrm{~min}$; (grey bars) glucoamylase activity at $40 \mathrm{~min}$ and (white bars) glucoamylase activity at $60 \mathrm{~min}$. 
The highest values of enzymatic activity and glucose obtained from maltose were at $\mathrm{pH} 4$ (4.4UI. $\mathrm{mg}^{-1}$ and $6,8 \mu \mathrm{molmL}^{-1}$, respectively) and a temperature of $60^{\circ} \mathrm{C}\left(5.6 \mathrm{UI} . \mathrm{mg}^{-1}\right.$ and $3.5 \mu \mathrm{mol}^{\mathrm{mL}} \mathrm{m}^{-1}$, respectively), as shown in Figure 3.

From these experimental design results, seven effects were found with a $P$ value lower than 0,05 and confidence level of $95 \%$. The results indicate that there was little or no interaction between the temperature and agitation. This is contrary to what is normally observed regarding interactions of $\mathrm{pH} /$ temperature and $\mathrm{pH} /$ agitation, with the latter typically being the most significant.

The polynomial obtained for glucoamylase activity (Equation 1) showed an R-squared value of $89.1 \%$ and an adjusted R-squared value of $87.7 \%$, which could explain the variability in enzymatic activity with a standard error of $0.4 \%$ and an absolute error of $0.3 \%$.

$$
\begin{aligned}
& \text { Glucoamylase activity }=103.29-52.81 . \mathrm{pH}+0.79 . \text { Temperature }-0.016 . \mathrm{rpm}+5.04 \mathrm{pH}^{2}+ \\
& \text { 0.074.pH.Temperature }+0.002 . \mathrm{pH} . \mathrm{rpm}-0.009 . \text { Temperature }^{2}+0.0000 \text { F5.Temperature.rpm }+ \\
& 0.000003 . \mathrm{rpm}^{2}
\end{aligned}
$$

From the mathematical model obtained to predict enzymatic activity, $\mathrm{pH}$ and $\mathrm{pH} 2$ were the most influential factors. From the response surface and surface contour (Figure 4) it can be concluded that the best saccharolytic activity obtained by the enzymatic extract was at an agitation of Orpm. Enzymatic activity was increased when the agitation increased to $4 \mathrm{rpm}$ at an average temperature of $55^{\circ} \mathrm{C}[25]$.

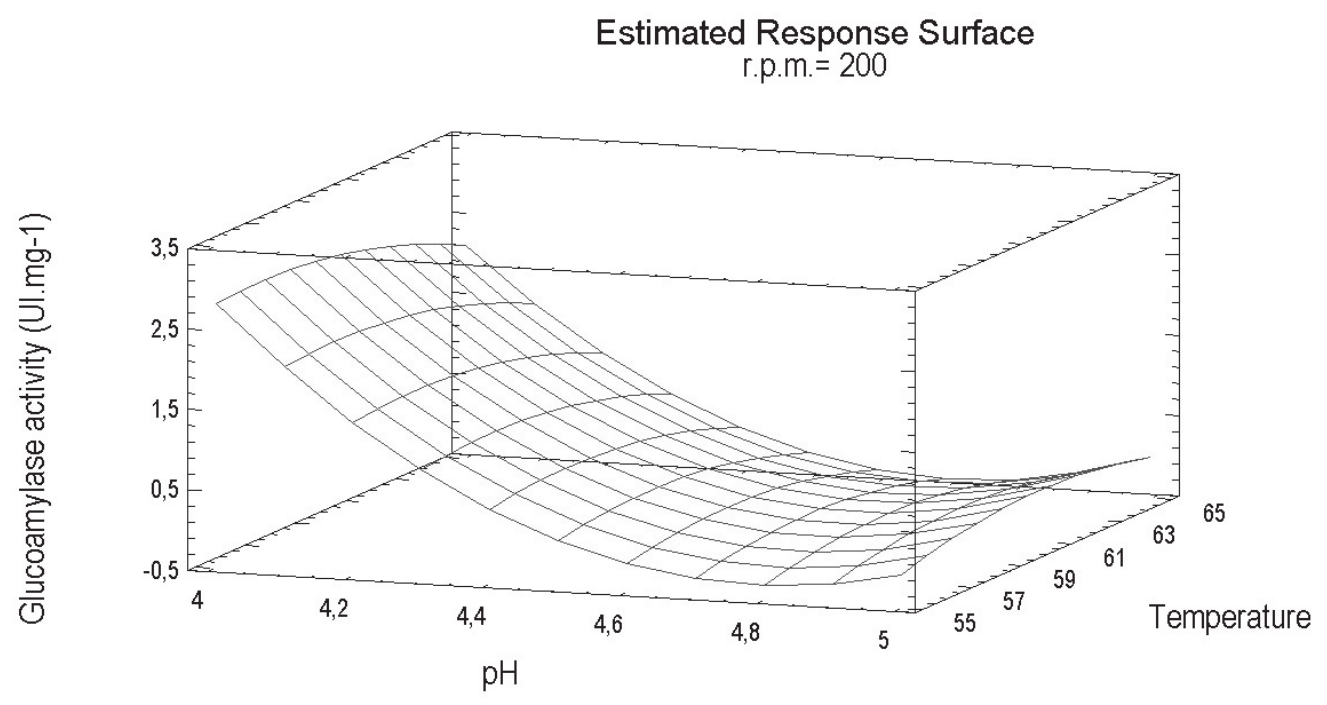

Figure 4. Response surface estimated of the combined effects of $\mathrm{pH}$ and temperature of enzymatic extract from Aspergillus A1, without agitation, $5 \mathrm{mgmL}^{-1}$ of maltose concentration at 15 minutes of reaction.

Enzymatic cofactor evaluation showed that all cofactors evaluated had a positive influence on enzymatic activity. The $\mathrm{Mg}^{2+}$ ion was found to increase enzymatic activity by $32 \%$, resulting in a value of $4.15 \mathrm{UI} . \mathrm{mg}^{-1}$.

Figure 5 shows that the use of metallic ions such as enzymatic cofactors increases enzymatic activity compared to the control. $\mathrm{Mg}^{+}$was the most influential factor, resulting in a $32.4 \%$ increase in enzymatic activity. This result agrees with that reported by Bhatti et al [15] and Benassi et al [26], who found a $176 \%$ increase in enzymatic activity using manganese ions in glucoamylase from Fusarium phoenicis. 


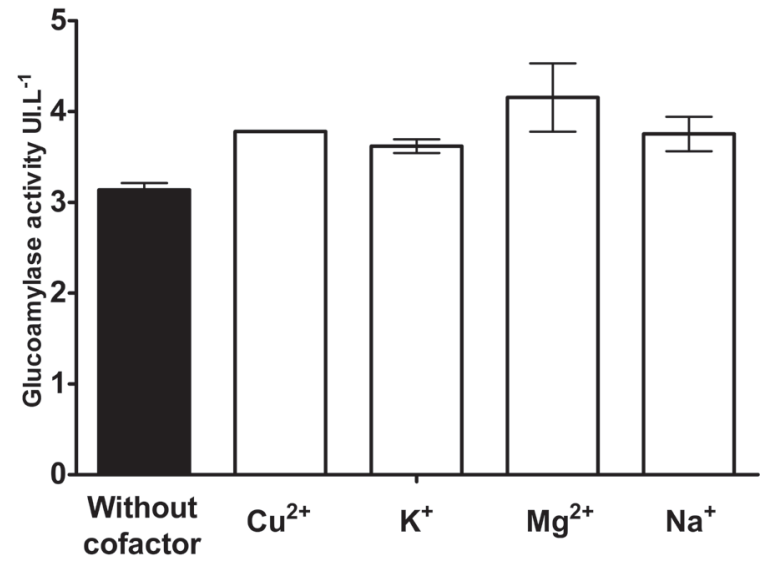

Figure 5. Effects of various metal ions at $1 \mathrm{mmol}$ concentration on glucoamylase activity, (black bar) control.

The thermal stability assay showed three periods of variation. The first 30 minutes of enzymatic activity peaked at $5.6 \mathrm{UI} . \mathrm{mg}^{-1}$, followed by a decrease by $22 \%$, and then the activity remained stable until 120 minutes. The enzymatic activity finally decreased to an average of $56 \%$ at the completion of the study.

The half-life determined for the enzymatic extract from Aspergillus A1 was 60 minutes of incubation at $60^{\circ} \mathrm{C}$, which was a similar time to that obtained by Sutthirak et al [27], who determined that the greatest decrease in enzyme activity occurred after two hours (Figure 6).

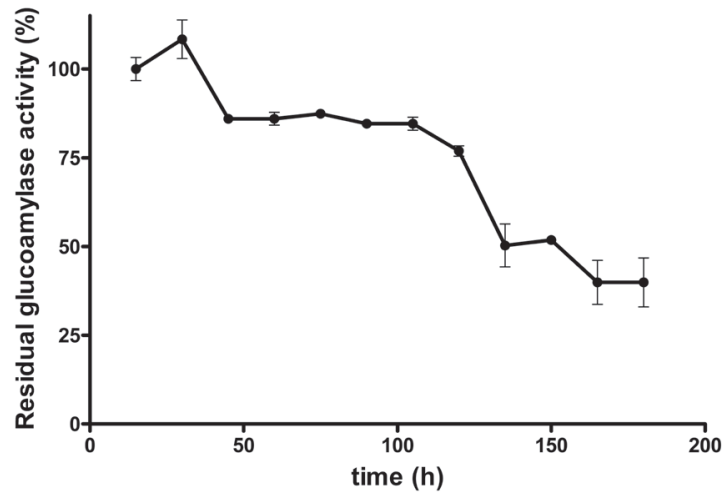

Figure 6. Thermal stability of enzymatic extract from Aspergillus $\mathrm{A} 1,5 \mathrm{mg} \mathrm{ml}^{-1}$ maltose concentration.

In saccharification assays of liquefied cassava starch, it has been found that saccharolytic activity has a glucose/enzymatic activity ratio of 0.9 for enzymatic extracts from Aspergillus A1. This is lower than that obtained by Ruiz et al [16], who found a value of 3.7 for purified commercial glucoamylase Spirizyme $®$ Fuel.

From 13 fungal isolations identified from decomposed cassava, the Aspergillus genera had the highest saccharolytic activity. From this group, it was possible to obtain an enzymatic extract with glucoamylase enzyme activity.

The SSF make it possible to obtain a higher protein concentration in enzymatic extracts from Aspergillus A1 for quantification and observation of the proteins by Bradford assay and electrophoresis, respectively.

The best parameters for maltose hydrolysis by enzymatic extracts from Aspergillus A1 were a $\mathrm{pH}$ of 4.0; a temperature of $55^{\circ} \mathrm{C}$ without agitation and $1 \mathrm{mmol} . \mathrm{L}^{-1}$ of $\mathrm{Mg}^{2+}$ cofactor.

It was confirmed that the enzymatic extract from native Aspergillus sp. could undergo saccharification of liquefied cassava starch.

\section{Acknowledgements}

The authors would like to thank the Ministry of Agricultura y Desarrollo Rural of Colombia (Project No. 026-2007D3321-639-07), the Dirección de Investigaciones de la Facultad de Salud de la Universidad Industrial de Santander for providing funding for this project (Project No. 5645)

\section{References}

[1] Faostat, 2016. Food and Agriculture Organization of The United Nations statistics division. Available in: http://faostat3.fao.org/ home/E\%22.

[2] Sorapipatana C, Yoosin S. Life cycle cost of ethanol production from cassava in Thailand. Renew sust energ rev. 2011;15:1343-9.

[3] Shanavas S, Padmaja G, Moorthy S, Sajeev M, Sheriff J. Process optimization for bioethanol production from cassava starch using novel eco-friendly enzymes. Biomass Bioenerg. 2001;35:901-9.

[4] Hebeda R. Enzymes in Food Processing, 3 ed. San Diego, USA. Academic press; 1993.

[5] Johnson R, Padmaja G, Moorthy S. Comparative production of glucose and high fructose syrup from cassava and sweet potato roots by direct conversion techniques Innov. Food Sci. Emerg. Technol. 2009;10:616-20.

[6] Bertoldo C, Antranikian G. Starch-hydrolyzing enzymes from thermophilic archaea and 
bacteria. Curr Opin Chem Biol. 2002;6:151-60.

[7] Klanarong S, Kuakoon P, Sittichoke W, Siriluck $\mathrm{N}$. The promise of a technology revolution in cassava bioethanol: from thai practice to the world practice Fuel. 2010;89:1333-8.

[8] Leveque E, Janecekc S, Hayea B, Belarbid A. Thermophilic archaeal amylolytic enzymes. Enzyme Microb. Technol. 2000;26:3-14.

[9] Sánchez C, Mejia C, Figueroa C, Esquivia M, Agudelo L, Zatapata N. Biospropección de microorganismos nativos amilolíticos. Vitae. 2004;2:8-17.

[10] Norouzian D, Akbarzadeh A, Scharer J, Young M. Fungal glucoamylases Biotechnol. Adv. 2006;24:80-5.

[11] Saldarriaga Y, Pineda F. Manual de Micología Aplicada, 1 ed. Medellin, Colombia. Universidad de Antioquia, 2001.

[12] Miller G. Use of Dinitrosalicylic Acid Reagent for Determination of Reducing Sugar Anal Chem. 1959;31:426-8.

[13] Biosystems. Glucose oxidase protocol. Avaible in: http://www.biosystems.es/products/ CLINICAL\%20DIAGNOSTICS/Biochemistry/ AUTOMATED\%20SYSTEMS/GIucose/ GLUCOSE-OXIDASE.

[14]Bradford M. A Rapid and sensitive method for the quantitation of microgram quantities of protein utilizing the principle of protein-dye binding Anal Biochem. 1974;72:248-54.

[15] Bhatti H, Rashid M, Nawaz R. Purification and characterization of a novel glucoamylase from Fusarium solani. Food Chem. 2007;103:33843.

[16]Ruiz M, Sanchez C, Torrres R, Molina D. Enzymatic Hydrolysis of Cassava starch for production of bioethanol with a colombian wild yeast strain J. Braz. Chem. Soc. 2001;2:233743.

[17]Buchholz K, Seibel J. Industrial carbohydrate biotransformations Carbohyd. Res. 2008;343:196679.

[18] Wang $Q$, Wang $X$, Wang $X$, Ma $H$.
Glucoamylase production from food waste by Aspergillus niger under submerged fermentation Process Biochem. 2007;43:280-6.

[19]Riaz M, Perveen R, Javed M, Nadeem $\mathrm{H}$, Rashid $\mathrm{M}$. Kinetic and thermodynamic properties of novel glucoamylase from Humicola sp. Enzyme Microb. Technol. 2007;41:558-64.

[20] O'Brien S, Wang Y. Susceptibility of annealed starches to hydrolysis by a-amylase and glucoamylase. Carbohyd. Polym. 2008;72:597607.

[21]Rodríguez S, Sanromán M. Application of solid-state fermentation to food industry $\mathrm{J}$. Food Eng. 2006;76:291-302.

[22] Singhania R, Patel A, Soccol C, Pandey A. Recent advances in solid-state fermentation Biochem. Eng. J. 2009;44:13-8.

[23] da Silva T, Maller A, de Lima A, Michelin D, Ward R, Hirata, I, Jorge J, Terenzi $H$, de Polizeli M. Properties of a purifie thermostable glucoamylase from Aspergillus niveus J. Ind. Microbiol. Biotechnol. 2009;36:1439-46.

[24]Bagheri A, Khodarahmi R, Mostafa A. Purification and biochemical characterisation of glucoamylase from a newly isolated Aspergillus niger: Relation to starch processing Food Chem. 2014;161:270-8.

[25] Slivinski C, Lopes A, Lulek J, Ayub R, de Almeida M. Biochemical Characterisation of a Glucoamylase from Aspergillus niger Produced by Solid-State Fermentation. Braz. Arch. Biol. Technol. 2001;54:559-68.

[26] Benassi V, Pasin T, Facchini F, Jorge J, De Moraes M. Novel glucoamylase activated by manganese and calcium produced in submerged fermentation by Aspergillus phoenicis. J Basic Microb. 2014;54:333-9.

[27] Sutthirak P, Dharmsthiti S, Lertsiri S. Effect of glycation on stability and kinetic parameters of thermostable glucoamylase from Aspergillus niger. Process Biochem. 2005;40:2821-6. 